\title{
The Writing, Observing and Getting Approach dalam Menciptakan Keunggulan Kompetitif Praktik Akuntansi Berbasis Excel for Accounting
}

\author{
Riski Aprilia Nita ${ }^{1}$, Nurmala Ahmar ${ }^{2}$ \\ ${ }^{1,2}$ STIE Perbanas Surabaya, Jalan Nginden Semolo 34-36 Surabaya 60118. Indonesia.
}

I N F O A R T I K E L

JEL Classification:

$\mathrm{I} 20$

L86

Keywords :

accounting practice,

excel for accounting,

competitive advantage,

accounting information system.

\section{A $B$ S T R A $\boldsymbol{C} T$}

In line with the development of accounting as an information system and the diversity of stakeholder information needs of the company makes accounting graduates are no longer viewed as an accountant who carry out manual recording process, but are required to be able to apply software designed to transform data into information that is useful in the world of work. Subjects accounting practices that integrate basic accounting and information systems also keep the demand for courses can be penciri competitive advantage that can accommodate students in understanding the business activity within an organization. In achieving these advantages is explained through a simple approach to understand the accounting cycle companies where students are expected to have the skills journaling (writing), carry out the analysis of the transaction (observing) and gain (getting) skills in applying accounting system-based computer using an application program based accounting Excel (Excel for Accounting).

\section{A B S T R A K}

Sejalan dengan perkembangan akuntansi sebagai suatu sistem informasi dan keberagaman kebutuhan informasi stakeholder perusahaan menjadikan lulusan akuntansi tidak lagi dipandang sebagai akuntan yang melaksanakan proses pencatatan manual, namun dituntut untuk dapat mengaplikasikan perangkat lunak yang dirancang untuk mentransformasi data menjadi informasi yang berguna dalam dunia kerja. Mata kuliah praktik akuntansi yang mengintegrasikan akuntansi dasar dan sistem informasi turut mengikuti tuntutan tersebut untuk dapat menjadi mata kuliah penciri yang dapat mengakomodasi keunggulan kompetitif mahasiswa dalam memahami aktivitas bisnis dalam suatu organisasi. Dalam mencapai keunggulan tersebut dijelaskan melalui pendekatan sederhana untuk memahami siklus akuntansi perusahaan dimana mahasiswa diharapkan memiliki keterampilan menjurnal (writing), melaksanakan analisis transaksi (observing) dan mendapatkan (getting) ketrampilan dalam mengaplikasikan sistem akuntansi berbasis komputer menggunakan program aplikasi akuntansi berbasis Excel (Excel for Accounting). 


\section{Pendahuluan}

Pendidikan akuntansi merupakan pembentuk kecerdasan intelektual, emosional, dan spriritual ketika mahasiswa harus memahami akuntansi (Sukoharsono, 2015). Demi mewujudkan lulusan yang mampu bersaing, kompeten dan beretika di bidang akuntansi berbegai pengembangan metode pengajaran dilakukan antara lain, pendidikan berbasis problem (Gasperz, 2015; Yuniarta, 2008), contextual, teaching, and learning (Musmini, 2012; Yuniarta, 2013), pembelajaran kooperatif (Sulistyani, 2014), berbasis multimedia (Riadi dan Ibrahim (2014; Fatimah, 2014). Praktik akuntansi menjadi mata kuliah yang cukup penting menjadi bekal lulusan akuntansi karena menyajikan seperangkat aplikasi siklus akuntansi kompleks meliputi konsep pembelajaran yang sudah didapatkan sebelumnya yaitu Pengantar Akuntansi, Akuntansi Biaya dan Akuntansi Keuangan. Akuntansi yang didefinisikan sebagai seni pencatatan, penggolongan dan peringkasan transaksi dan kejadian yang bersifat keuangan dengan cara yang berdaya guna dan dalam bentuk satuan uang (Accounting Principle Board) lambat laun mengalami pergeseran karena adanya perkembangan dunia bisnis yang sangat berpengaruh terhadap fungsi akuntansi dan perkembangan praktik akuntansi.

Tarmizi (2015) melakukan kajian terkait spesifikasi keahlian akuntansi pada program vokasi, dan hasilnya adalah bahwa terdapat 3 bidang pengetahuan utama yang dipersyaratkan bagi kurikulum pendidikan akuntansi, yaitu: 1. accounting, finance and related knowledge; 2. organizational and business knowledge; dan 3. information technology knowledge and competences. Berdasarkan temuan tersebut, pengetahuan teknologi informasi merupakan kompetensi penting yang tergali dari temuan riset tersebut. Oleh karenanya banyak temuan riset tentang penguatan kompetensi teknologi di bidang akuntansi dan implementasinya dalam dunia bisnis. Hal ini didukung adanya temuan empiris bahwa keterampilan dosen mengajar pada lingkungan kampus mempengaruhi motivasi mereka dalam belajar (Anisaturizqi dan Nurkhin, 2015). Temuan lebih lanjut sebagai tidak lanjut pengembangan aplikasi akuntansi dilakukan oleh Yuniarta (2015). Peneliti ini mengembangkan software kamus akuntansi untuk rumah sakit, pengembangan multimedia untuk perangkat simulasi akuntansi untuk usaha kecil (Yuniarsa, 2013), belajar langsung secara living laboratory pada usaha kecil menengah (Santoso dan Ivada, 2015). Sementara Diatmika (2012) mengembangkan kamus daftar akun/rekening untuk bisnis perhotelan.

Statements of Accounting Principles Board No. 4 (1970) mendefinisikan akuntansi adalah kegiatan penyediaan jasa. Fungsinya adalah menyediakan informasi kuantítatif tentang unit-unit usaha ekonomik, terutama yang bersifat keuangan, yang diperkirakan bermanfaat dalam pengambilan keputusan ekonomik. Data harus diproses terlebih dahulu dan disajikan sesuai dengan kebutuhan pemakai tertentu untuk menjadi informasi. Sistem informasi akuntansi berperan penting untuk mengubah data keuangan ke dalam informasi. End-user computation akhirnya digunakan untuk menjalankan fungsi akuntansi menggunakan perangkat lunak database atau komputer personal (Bodnar, 2004)

Kesulitan lulusan dalam mengolah data akuntansi dalam dunia bisnis akhirnya dapat diselesaikan menggunakan sistem berbasis komputer. Namun tidak semua perusahaan juga memiliki kompatibilitas dalam menggunakan perangkat lunak akuntansi. Selain itu, jika organisasi bisnis telah memiliki perangkat lunak yang kompatibel, permasalahan terletak pada sumber daya yang dituntut untuk dapat beradaptasi terhadap sistem. Permasalahan ini membawa pengusul untuk berusaha menggunakan aplikasi perangkat lunak yang lebih universal dan familiar digunakan baik oleh end-user maupun pemakai informasi akuntansi, yaitu menggunakan microsoft excel.

Microsoft Excel atau Microsoft Office Excel adalah sebuah program aplikasi lembar kerja spreadsheet yang dibuat dan didistribusikan oleh Microsoft Corporation untuk sistem operasi Microsoft Windows dan Mac OS. Aplikasi ini 
memiliki fitur kalkulasi dan pembuatan grafik yang, dengan menggunakan strategi marketing Microsoft yang agresif, menjadikan Microsoft Excel sebagai salah satu program komputer yang populer digunakan di dalam komputer mikro hingga saat ini. Bahkan, saat ini program ini merupakan program spreadsheet paling banyak digunakan oleh banyak pihak, baik di platform PC berbasis Windows maupun platform Macintosh berbasis Mac OS, semenjak versi 5.0 diterbitkan pada tahun 1993 (Wikipedia, 2012). Karena program spreadsheet ini paling banyak digunakan oleh banyak pihak, maka dapat dipastikan bahwa organisasi bisnis yang mengadopsi Microsoft pasti memiliki program aplikasi ini.

Program Aplikasi Akuntansi berbasis Excel adalah program aplikasi yang siap untuk mendukung Anda dalam menghadapi dunia kerja. Aplikasi tersebut akan memudahkan kita melaksanakan praktik-praktik akuntansi dalam dunia kerja. Dalam dunia kerja, belum tentu disediakan software atau program pengolah data akuntansi. Umumnya hanya disediakan program pengolah data Excel. Program Aplikasi Akuntansi berbasis Excel sangat mendukung hal tersebut karena berjalan di Excel. Sehingga apabila terbiasa dengan Excel, akan sangat mudah menggunakannya. Berdasarkan pengembangan teori tersebut, pengembangan metode pembelajaran yang diharapkan dapat meningkatkan kompetensi lulusan dan memberikan pemahaman mahasiswa terhadap fungsi akuntansi berbasis komputer.

Artikel ini merupakan paparan hasil desain/rancangan pengembangan mata kuliah Praktik Akuntansi berbasis teknologi yang diharapkan mampu memberikan gambaran implementasi pada perguruan tinggi khususnya program Studi Akuntansi yang difokuskan pada pemanfaat software pengolah angkat (spreadsheet) Microsoft Excel secara advanced.

\section{Fokus dan Metode}

Fokus penelitian adalah system informasi akuntansi berbasis software pengolah angka Microsoft Excel. Desain dilakukan dengan mengembangan literatur yang ditulis oleh Ahmar dan Tjahjono (2011) tentang penggunaan Ms.Excel dalam penyusunan laporan keuangan perusahaan multi divisional. Ujicoba dilakukan dalam kelas mata kuliah Praktik Akuntansi dan kemudian ditetapkan sebagai metode dan konten pembelajaran sebagaimana dipaparkan pada tulisan ini. Tempat observasi dan desain adalah satu sekolah tinggi ilmu ekonomi pada Program Studi Akuntansi. Desain transaksi, dokumen, logika hubungan relasional antar fungsi mengacu pada Ahmar dan Tjahjono (2011). Sumber data sampel transaksi bersumber dari modul Praktik akuntansi yang berisi kumpulan bukti transaksi berupa faktur jual, faktur beli, bukti kas masuk, bukti kas keluar, bukti pemakaian bahan dan bukti memorial. Total transaksi yang digunakan sebagai sampel transaksi adalah transaksi selama 1 bulan sebanyak 255 sampel transaksi. Sistem pembelajaran yang didesain menggunakan pendekatan writing, observing and getting. Writing mewakili kemampuan untuk menuliskan jurnal sebagai dasar pemahaman siklus akuntansi. Observing mewakili tindakan atau aktualisasi dalam mengamati maupun menganalisa transaksi yang terjadi dalam periode pelaporan perusahaan manufaktur. Sedangkan getting merepresentasikan kemampuan untuk mendapatkan keterampilan mengaplikasikan dan membuat desain manual guide untuk siklus akuntansi perusahaan manufaktur dengan alat bantu komputer menggunakan spreadsheet Excel for Accounting.

\section{Hasil Penelitian dan Pembahasan}

Pendekatan writing, observing and getting digunakan untuk memudahkan sistem pembelajaran praktik akuntansi berbasis Excel for Accounting (EFA). Adapun penjelasan terinci mata kuliah adalah sebagai berikut: Nama Mata Kuliah (SKS): Mata kuliah ini bernama Praktik Akuntansi. Mata kuliah ini dilaksanakan secara berurutan dalam dua tahap selama seminggu yang terdiri dari kelas teori dan praktika. Kelas teori memiliki bobot 2 SKS yang setara dengan 100 menit, sedangkan kelas praktika memiliki 
bobot 0 SKS yang setara dengan 150 menit.

1. Deskripsi Umum Mata Kuliah: Mata kuliahini dirancang agar mahasiswa dapat memahami siklus akuntansi perusahaan manufaktur melalui analisis transaksi, terampil dalam menjurnal dan menyusun laporan keuangan perusahaan manufaktur secara manual serta memiliki kemampuan dalam melakukan input, identifikasi fungsi dan media entry data menggunakan spreadsheet Microsoft Excel beserta manual user guide atas aplikasi sistem tersebut.

2. Tujuan Pembelajaran: Adapun tujuan pembelajaran mata kuliah ini menggunakan the wrong approach adalah memberikan pengetahuan dan keterampilan kepada mahasiswa tentang :

a) Analisis transaksi penjualan, pembelian, penerimaan dan pengeluaran kas, serta transaksi umum yang terkait dengan perusahaan manufaktur termasuk alokasi biaya dan perhitungan harga pokok produksi.

b) Kemampuan menjurnal serta menyusun laporan keuangan perusahaan manufaktur dengan cara manual.

c) Aplikasi dan desain manual guide untuk siklus akuntansi perusahaan manufaktur dengan alat bantu komputer menggunakan spreadsheet Excel for Accounting.

3. Jumlah Modul (Unit/Bab): Modul pembela- jaran yang digunakan pada mata kuliah ini berjumlah 1 (satu) modul komprehensif dengan halaman sampul yang ditunjukkan pada Gambar 1.

Dalam mendukung pembelajaran the writing, observing and getting approach kepada mahasiswa, secara berurutan modul ini memiliki bagian yang merepresentasikan siklus akuntansi perusahaan manufaktur. Adapun unit/bab dalam modul tersebut terdiri dari :

1. Informasi Umum. Bab ini memuat tentang gambaran umum perusahaan, proses produksi, pemasaran dan struktur organisasi.

2. Ikhtisar Kebijakan Akuntansi. Bab ini memuat pelaksanaan sistem dan kebijakan akuntansi terkait dengan proses pencatatan, jurnal penyesuaian, kas kecil, depresiasi, amortisasi, persediaan dan alokasi biaya.

3. Pedoman Rekening. Bab ini memuat tentang dasar klasifikasi rekening buku besar, susunan dan penjelasan kode rekening yang digunakan dalam pelaporan keuangan.

4. Instruksi Praktikum. Bab ini memuat tugas yang harus dilaksanakan selama satu semester yang terdiri dari instruksi akuntansi keuangan, akuntansi biaya dan penyusunan laporan keuangan.

5. Bukti Transaksi. Bab ini memuat gambaran bukti transaksi perusahaan manufaktur yang terdiri dari faktur, bukti kas masuk, bukti kas keluar, bukti pemakaian barang, bukti memorial dan kartu persediaan.

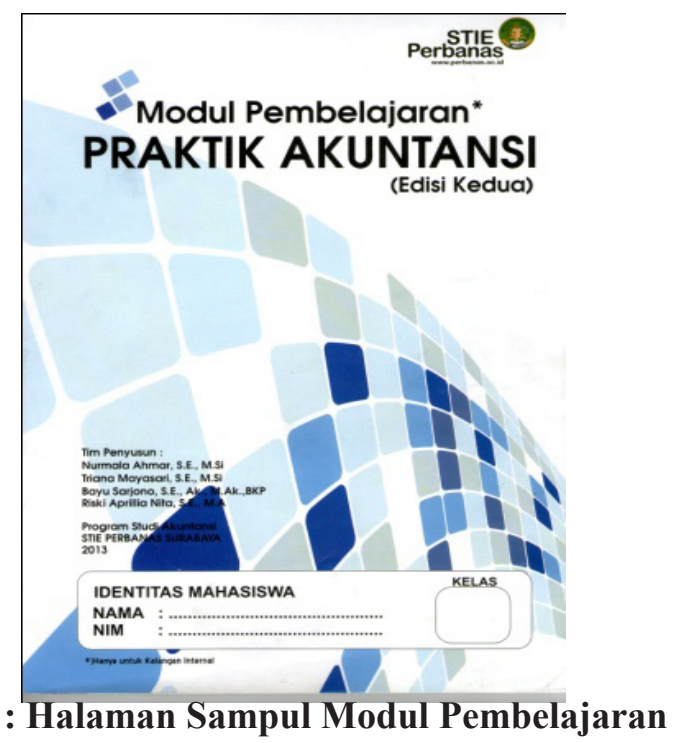


Mahasiswa diminta untuk mencatat jurnal yang terkait dengan bukti transaksi tersebut dan menyelesaikan kartu persediaan untuk menentukan harga pokok penjualan. Contoh bukti transaksi pada modul pembelajaran ditunjukkan pada Gambar 2. transaksi sampai dengan menghitung harga pokok produk dalam laporan biaya produksi departemen produksi. Contoh formulir pada modul pembelajaran ditunjukkan pada Gambar 3.

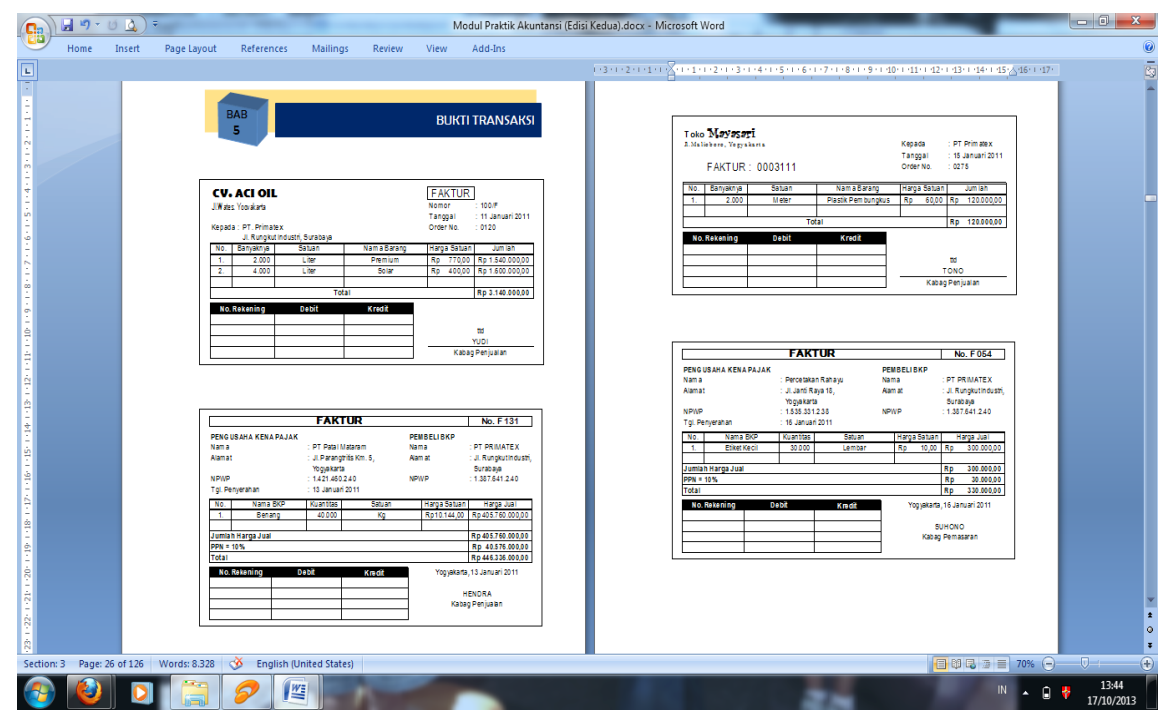

Gambar 2 : Contoh Bukti Transaksi

6. Formulir. Bab ini memuat format rekapitulasi jurnal transaksi yang terdiri dari jurnal pembelian, jurnal penjualan, jurnal penerimaan kas, jurnal pengeluaran kas, jurnal pemakaian barang, jurnal memorial, rekapitulasi biaya dan alokasi biaya overhead pabrik serta laporan biaya produksi departemen men produksi. Mahasiswa diminta untuk melakukan posting pada masing-masing jurnal sesuai dengan bukti -
7. Contoh Desain Excel for Accounting dan Penyusunan Laporan Keuangan. Bab ini memuat tentang rekapitulasi saldo awal, contoh desain saldo awal, contoh desain jurnal umum, contoh desain alokasi biaya, contoh desain ledger, contoh desain laporan laba rugi dan neraca, neraca lajur, laporan laba-rugi dan neraca. Adapun waktu yang dibutuhkan dalam menyelesaikan modul keseluruhan dalam satu semester dapat dilihat pada Tabel 1.

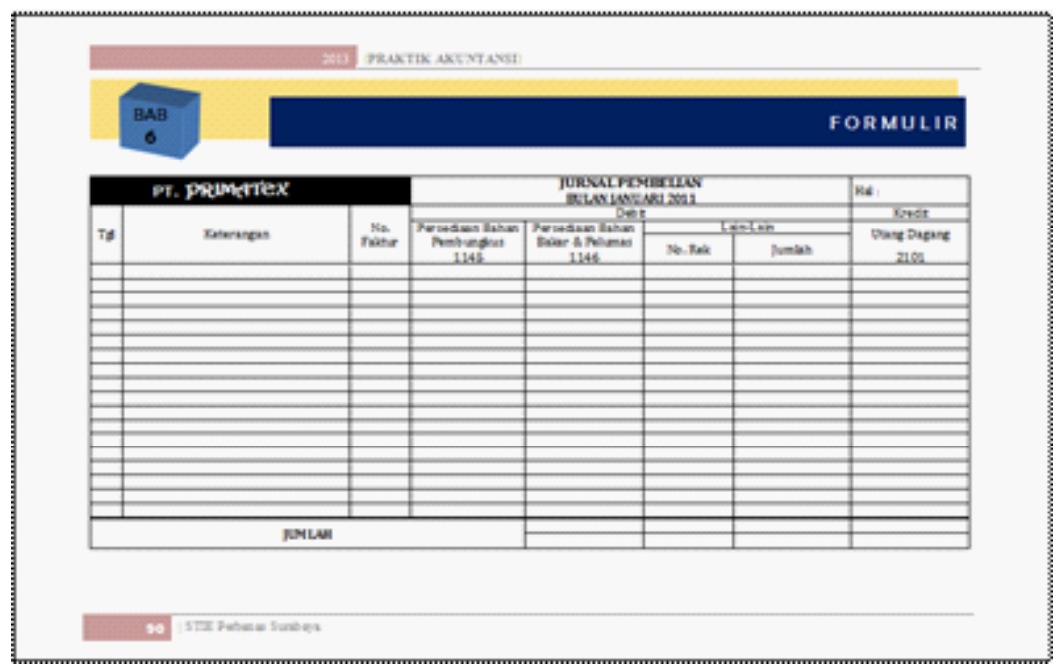

Gambar 3 : Contoh Formulir 
Tabel 1. Alokasi Waktu

\begin{tabular}{lccc}
\hline \multicolumn{1}{c}{ Keterangan } & Teori & Praktika & Jumlah \\
\hline Jumlaj Jam / SKS & 1,67 Jam & 2,5 Jam & 4,17 Jam \\
Jumlah tatap muka & 14 Kali & 14 Kali & 28 Kali \\
Jumlah Jam & 23, 38 Jam & 35 Jam & 58,38 Jam \\
\hline
\end{tabular}

Alokasi jam dan pembagian mingguan untuk perkuliahan ini sesuai dengan materi perkuliahan Praktek Akuntansi, yang terdiri dari:

1. 60 menit pertama tutorial dosen atas materi yang akan disampaikan.

2. $30 / 80$ menit berikutnya penyelesaian tugas terstruktur yang dilakukan secara mandiri berdasarkan modul.

3. 10 menit terakhir pembahasan tugas dan penilaian.

Sumber daya pembelajaran Adapun usaha yang dilakukan untuk dapat meningkatkan hasil pembelajaran berasal dari literatur yang terdiri dari:

1. Tim Pengajar Praktek Akuntansi. 2013. Modul Pembelajaran : Praktik Akuntansi (Edisi Kedua). STIE Perbanas Surabaya (Buku 1)

2. Nurmala Ahmar dan Iwan Tri Tjahjono. 2011. Excel for Accounting : Panduan Praktis Menyusun Laporan Keuangan Perusahaan dengan Microsoft Excel. STIE Perbanas Press (Buku 2)

Pembelajaran akan banyak menekankan peran aktif mahasiswa dalam memahami, menganalisis bukti transaksi dan pengisian lembar kerja. Adapun penilaian pembelajaran disusun sebagai berikut :

1. Komponen penilaian tengah semester pada mata kuliah ini diperoleh dari upaya individu dalam bentuk penyelesaian modul pembelajaran dengan tepat. Mahasiswa diminta mengerjakan modul secara urut sesuai materi dan akan dinilai setelah pekerjaan selesai.

2. Komponen penilaian akhir semester diperoleh berdasarkan pekerjaan kelompok dalam mengaplikasikan spreadsheet Excel for Accounting. Mahasiswa diminta melakukan input, identifikasi fungsi dan Manual User Guide Excel for Accounting di perusahaan manufaktur sesuai dengan modul yang telah diselesaikan pada tengah semester.

3. Tidak ada toleransi terhadap keterlambatan penyerahan/pengumpulan tugas kecuali dengan alasan yang dapat dipertanggungjawabkan. Plagiat dan mencontek dapat membatalkan komponen penilaian yang terkait.

Standar Penilaian atas keberhasilan mahasiswa dalam mengikuti dan memahami materi pada mata kuliah ini didasarkan penilaian selama proses perkuliahan dan nilai ujian, dengan komposisi seperti pada Tabel 2.

\section{Tabel 2. Instrumen Penilaian Kinerja Kompetensi Praktik Akuntansi}

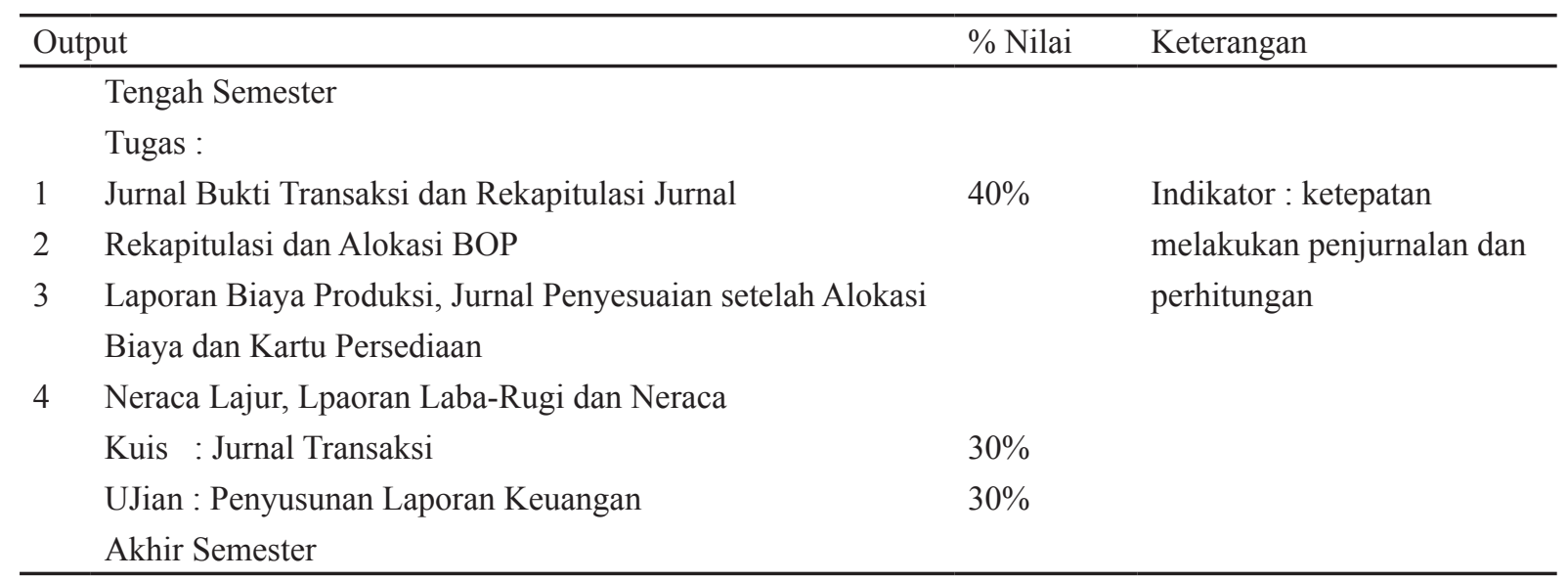




\begin{tabular}{|c|c|c|c|}
\hline & Output & $\%$ Nilai & Keterangan \\
\hline & Tengah Semester & & \\
\hline & Tugas : & & \\
\hline 5 & Jurnal Bukti Transaksi dan Rekapitulasi Jurnal & $40 \%$ & Indikator : ketepatan \\
\hline 6 & Rekapitulasi dan Alokasi BOP & & melakukan penjurnalan dan \\
\hline \multirow[t]{2}{*}{7} & Laporan Biaya Produksi, Jurnal Penyesuaian setelah Alokasi & & perhitungan \\
\hline & Biaya dan Kartu Persediaan & & \\
\hline \multirow[t]{5}{*}{8} & Neraca Lajur, Laporan Laba-Rugi dan Neraca & & \\
\hline & Kuis : Jurnal Transaksi & $30 \%$ & \\
\hline & Ujian : Penyusunan Laporan Keuangan & $30 \%$ & \\
\hline & Akhir Semester & & \\
\hline & Tugas - Input dan Indentifikasi Excel for Accounting: & & \\
\hline 1 & Sheet Ledger dan Forum Identifikasi & $40 \%$ & nilai maksimum $=20$ \\
\hline 2 & Sheet Jurnal dan Form Identifikasi & & nilai maksimum $=20$ \\
\hline 3 & Sheet Alokasi dan Form Identifikasi & & nilai maksimum $=20$ \\
\hline \multirow[t]{2}{*}{4} & Input Transaksi & & \\
\hline & Kuis - Input dan identifikasi Excel for Accounting : & & \\
\hline 1 & Sheet Costing dan Form Identifikasi & $40 \%$ & nilai maksimum $=40$ \\
\hline 2 & Sheet Ledger dan Form Identifikasi & & nilai maksimum $=40$ \\
\hline 3 & Sheet Stock dan Form Identifikasi & & nilai maksimum $=40$ \\
\hline \multirow[t]{2}{*}{4} & Input Transaksi & & \\
\hline & $\begin{array}{l}\text { Ujian - Desain Excel for Accounting: Desain Komperhensif } \\
\text { dan Manual User Guide }\end{array}$ & $20 \%$ & \\
\hline
\end{tabular}

Desain pembelajaran menggunakan the writing, observing and getting approach terbagi menjadi des basis spreadsheet yang ditunjukkan dalam gambar sebagai berikut :

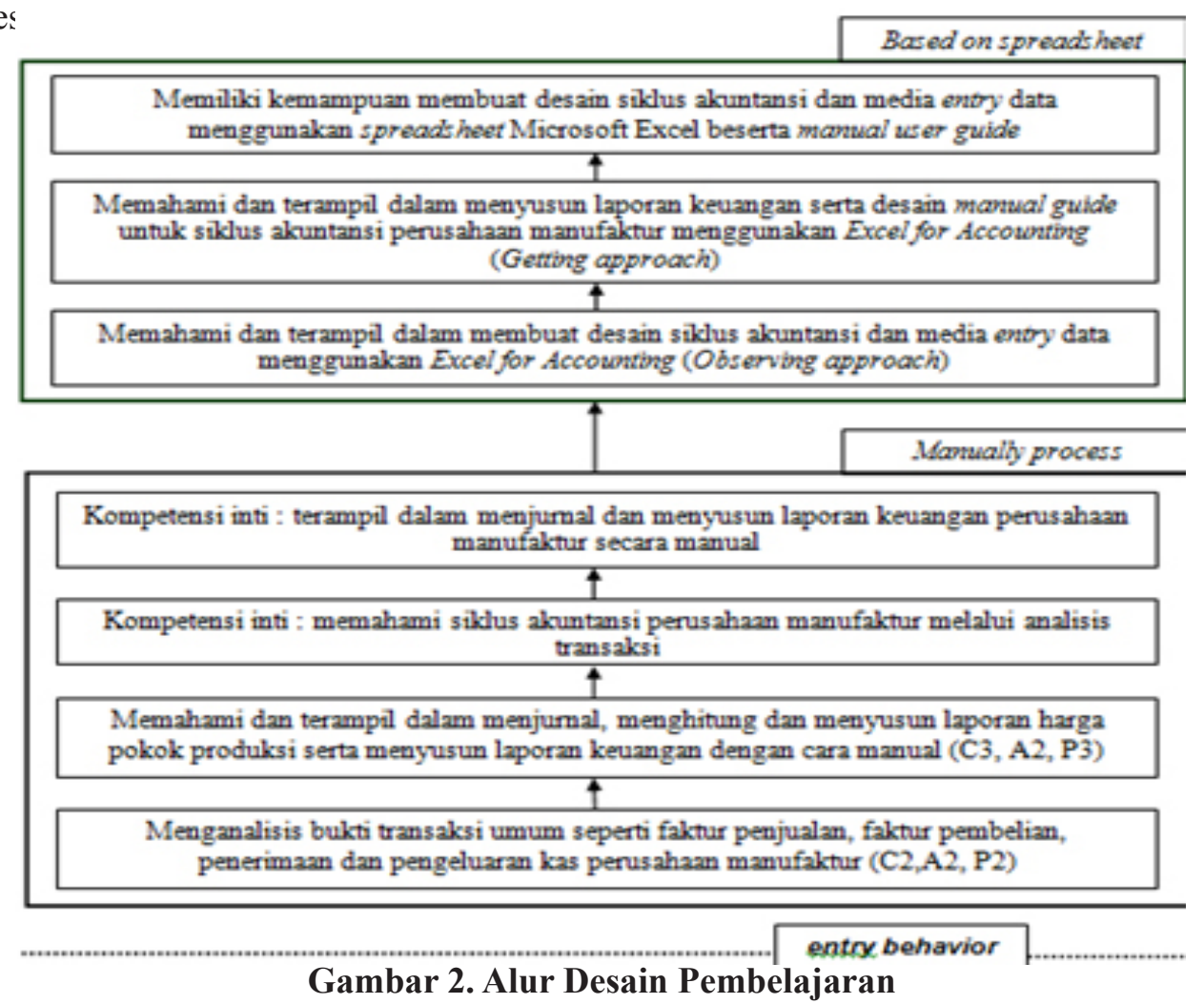


Pelaksanaan desain pembelajaran tersebut terintegrasi pada setiap tatap muka perkuliahan baik kelas teori maupun praktika dengan penjelasan sebagai berikut :

1. Tahap desain manually process

Obyek pembelajaran pada tahap ini terbagi menjadi dua tahap, antara lain :

a. Menganalisis bukti transaksi umum seperti faktur penjualan, faktur pembelian, penerimaan dan pengeluaran kas perusahaan manufaktur.

b. Memahami dan terampil dalam menjurnal, menghitung dan menyusun laporan harga pokok produksi serta menyusun laporan keuangan dengan cara manual.

Sumber pembelajaran yang digunakan adalah modul pembelajaran yang dibuat tim pengajar. Penilaian tahap ini didasarkan pada upaya individu dalam bentuk penyelesaian modul pembelajaran dengan tepat. Standar penilaian berupa ketepatan melakukan penjurnalan dan perhitungan.

Tabel 3. Distribusi Tatap Muka
2. Tahap desain based on spreadsheet Obyek pembelajaran pada tahap ini terbagi menjadi dua tahap, antara lain :

a. Memahami dan terampil dalam membuat desain siklus akuntansi dan media entry data menggunakan Excel for Accounting.

b. Memahami dan terampil dalam menyusun laporan keuangan serta desain manual guide untuk siklus akuntansi perusahaan manufaktur menggunakan Excel for Accounting.

Sumber pembelajaran yang digunakan adalah modul pembelajaran yang dibuat tim pengajar dan buku yang sudah direferensikan sebagai dasar dalam memahami konsep aplikasi Excel for Accounting. Penilaian tahap ini didasarkan pada upaya kelompok dalam melaksanakan input data, identifikasi fungsi relasi, formula dan dampak perubahan aplikasi dalam sebuah formulir. Standar penilaian berupa ketepatan melakukan input data dan kelengkapan identifikasi. Adapun aktivitas pembelajaran yang dilaksanakan selama 14 kali tatap muka perkuliahan teori dan praktika ditunjukkan melalui Tabel 3.

\begin{tabular}{|c|c|c|}
\hline $\begin{array}{c}\text { Minggu } \\
\text { ke - }\end{array}$ & Kelas Teori & Kelas Praktika \\
\hline 1 & $\begin{array}{l}\text { Kontrak Pembelajaran dan Instruksi Umum } \\
\text { Modul Pembelajaran }\end{array}$ & $\begin{array}{l}\text { Jurnal Bukti Transaksi : Faktur, Bukti Kas Masuk } \\
\text { dan Kas Keluar }\end{array}$ \\
\hline 2 & $\begin{array}{l}\text { Jurnal Bukti Transaksi : Bukti } \\
\text { Pemakaian Barang }\end{array}$ & $\begin{array}{l}\text { Jurnal Bukti Transaksi : Bukti Pemakaian Barang } \\
\text { dan Memorial }\end{array}$ \\
\hline 3 & $\begin{array}{l}\text { Rekapitulasi Jurnal : Faktur, Bukti Kas } \\
\text { Masuk dan Kas Keluar }\end{array}$ & $\begin{array}{l}\text { Rekapitulasi Jurnal : Bukti Pemakaian Barang dan } \\
\text { Memorial }\end{array}$ \\
\hline 4 & Kuis : Jurnal Transaksi & Rekapitulasi dan Alokasi BOP (1) \\
\hline 5 & Rekapitulasi dan Alokasi BOP (2) & $\begin{array}{l}\text { Laporan Biaya Produksi Sie Persiapan dan Perte- } \\
\text { nunan }\end{array}$ \\
\hline 6 & $\begin{array}{l}\text { Jurnal Penyesuaian setelah Alokasi Biaya, } \\
\text { Neraca Lajur (1) }\end{array}$ & Neraca Lajur (2) \\
\hline 7 & Laporan Laba-Rugi & Neraca \\
\hline \multicolumn{3}{|c|}{ UTS : Penyusunan Laporan Laba-Rugi dan Neraca Perusahaan Manufaktur } \\
\hline 8 & Penjelasan Excel for Accounting & $\begin{array}{l}\text { 1. Entri Saldo Awal } \\
\text { 2. Identifikasi Perubahan Aplikasi Excel for Ac- } \\
\text { counting: sheet Ledger }\end{array}$ \\
\hline 9 & $\begin{array}{l}\text { Entri Jurnal : Faktur Jual, Faktur Beli dan } \\
\text { Bukti Kas Masuk }\end{array}$ & $\begin{array}{l}\text { Entri Jurnal : Bukti Kas Keluar dan Bukti Pemaka- } \\
\text { ian Barang }\end{array}$ \\
\hline
\end{tabular}




\begin{tabular}{|c|c|c|}
\hline 10 & Entri Jurnal : Bukti Memorial & $\begin{array}{l}\text { Identifikasi Perubahan Aplikasi Excel for Account- } \\
\text { ing : sheet Jurnal }\end{array}$ \\
\hline 11 & Saldo Akhir Ledger dan Neraca Lajur & $\begin{array}{l}\text { 1. Alokasi Biaya } \\
\text { 2. Identifikasi Perubahan Aplikasi Excel for Ac- } \\
\text { counting : sheet Alokasi }\end{array}$ \\
\hline 12 & Laporan Biaya Produksi & $\begin{array}{l}\text { Identifikasi Perubahan Aplikasi Excel for Account- } \\
\text { ing : sheet Costing dan sheet Ledger }\end{array}$ \\
\hline 13 & 1. Persediaan & 1. Laporan Laba Rugi dan Neraca \\
\hline & $\begin{array}{l}\text { 2. Identifikasi Perubahan Aplikasi Excel } \\
\text { for Accounting : sheet Stock }\end{array}$ & 2. Rekapitulasi Form Identifikasi \\
\hline 14 & Penyusunan Manual User Guide & Penyusunan Manual User Guide \\
\hline
\end{tabular}

\section{Kesimpulan, Keterbatasan, dan Implikasi Hasil Penelitian}

Penelitian ini merupakan hasil desain model pendekatan pengajaran mata kuliah Praktik Akuntansi dengan pendekatan writing, observing and getting. Writing mewakili kemampuan untuk menuliskan jurnal sebagai dasar pemahaman siklus akuntansi. Observing mewakili tindakan atau aktualisasi dalam mengamati maupun menganalisa transaksi yang terjadi dalam periode pelaporan perusahaan manufaktur. Sedangkan getting merepresentasikan kemampuan untuk mendapatkan keterampilan mengaplikasikan dan membuat desain manual guide untuk siklus akuntansi perusahaan manufaktur dengan alat bantu komputer menggunakan spreadsheet Excel for Accounting.

Hasil penelitian merupakan software aplikasi akuntansi manufaktur yang mampu mengolah datatransaksimenjadilaporankeuangan dalam bentuk laporan laba rusi, arus kas, laporan posisi keuangan, dan laporan perubahan ekuitas. Aplikasi berb asis software pengolah angka Microsoft Excel dimanfaatkan secara optimum dengan memanfaatkan fungsi-fungsi yang mampu digunakan untuk mengkonsolidasi data antar sheet. Mahasiswa diberikan pemahaman bahwa rutinitas aktivitas transaksi akuntansi dapat didesain sistemnya sedemikian rupa sehingga pelaporan keuangan yang rumit menjadi lebih mudah. Upaya penugasan menyusun petunjuk operasi manual adalah bentuk nyata bahwa jika pemakai membaca petunjuk operasi manual tersebut (manual user guide) maka dengan mudah pemakai (users) dapat memanfaat aplikasi pada berbagai bidang bisnis, tidak hanya sekedar perusahaan dari sector industry manufaktur. Sektor industry lain juga dapat memanfaatkan aplikasi tersebut untuk mengolah data transaksinya menjadi laporan keuangan. Riset mendatang dapat mengkolaborasikan hasil desain yang dilakukan oleh Yuniarta (2015) atau Diatmika (2012) agar daftar akun atau istilahistilah penting dalam akuntansi terakomodir dalam desain system yang baru. Riset tersebut juga dapat menjadi media kolaborasi antara bidang akuntansi dan teknik informasi.

\section{Daftar Pustaka}

Ahmar, N., Tjahjono., I.T., (2011). Excel for Accounting : Panduan praktis menyusun laporan keuangan perusahaan dengan microsoft excel. STIE Perbanas Press

Anisaturizqi, I., \& Nurkhin, A. (2015). Pengaruh keterampilan mengajar dosen dan lingkungan kampus terhadap motivasi belajar mahasiswa pendidikan akuntansi Universitas Negeri Semarang angkatan 2013. Economic Education Analysis Journal, 4(3).

Bodnar, George $\mathrm{H}$ and William S. Hopwood. 2006. Sistem informasi akuntansi, Edisi 9 
(terjemahan). Yogyakarta : Penerbit Andi

Diatmika, I. P. G. (2012). Pengembangan kamus" chart of accounts" untuk mata kuliah akuntansi perhotelan. Jurnal Ilmu Sosial Dan Humaniora, 1(1).

Fatimah, S. (2014). Penggunaan multimedia untuk meningkatkan hasil belajar mahasiswa pada mata kuliah akuntansi perbankan di Program Studi Pendidikan Ekonomi. In Jurnal Forum Sosial (Vol. 7, No. 1, Pp. 403-408). Jurusan Pendidikan Ilmu Pengetahuan Sosial Fakultas Keguruan Dan Ilmu Pendidikan Universitas Sriwijaya.

Gasperz, J. (2015). Pengaruh model pembelajaran akuntansi berbasis problem terhadap peningkatan softskills mahasiswa jurusan akuntansi pada Ptn dan Pts di Kota Ambon. Dinamika Akuntansi Keuangan Dan Perbankan, 4(1).

Lunarto, I., \& Sugiarti, Y. (2014). Analisis manfaat quality assurance dalam meningkatkan kualitas hasil pembelajaran pada Jurusan Akuntansi Fakultas Bisnis dan Ekonomika Universitas Surabaya. Calyptra: Jurnal Ilmiah Mahasiswa Universitas Surabaya, 3(1).

Maulana, N. (2015). Pengaruh grade mata kuliah akuntansi keuangan yang diperoleh mahasiswa akuntansi terhadap kompetensi penyusunan laporan keuangan (Studi empiris pada mahasiswa jurusan akuntansi, Fakultas Ekonomi Untan yang sedang menempuh perkuliahan akuntansi keuangan La. Jurnal Kajian Ilmiah Akuntansi Fakultas Ekonomi Untan (Kiafe), 4(1).

Musmini, L. S. (2012). Pengembangan perangkat visualisasi komputer sistem akuntansi berbasis Ict dengan model pembelajaran berpendekatan Ctl. Jurnal Pendidikan Indonesia, 1(1).

Riadi, R. M., \& Ibrahim, B. (2014). Pengembangan model pembelajaran berbasis multimedia pada mata kuliah komputer akuntansi. Pekbis (Jurnal Pendidikan Ekonomi Dan Bisnis), 6(2), 105-115.

Santoso, S., \& Ivada, E. (2015). Pengembangan living laboratory pendidikan akuntansi melalui edukasi akuntansi pada Umkm (Observasi dan identifikasi pada Umkm di kota Solo, Wonogiri, Sukoharjo, Klaten, Sragen, Boyolali, dan Karanganyar). In Prosiding Seminar Nasional Pendidikan Akuntansi Dan Keuangan.

Sukoharsono, E. G. (2015). Pendidikan akuntansi sebagai pembentuk kecerdasan intelektual, emosional dan spiritual mahasiswa dalam memahami akuntansi: Studi fenomenologis. Jurnal Ilmiah Mahasiswa Feb, 3(1).

Sulistyani, L. (2014). Wacana pemgembangan model pembelajaran kooperatif mata kuliah dasar-dasar akuntansi pada Perguruan Tinggi. Informatika, 1(2).

Tarmizi, T. (2015). Kajian spesifikasi keahlian akuntansi pada kurikulum penyelenggara Program Diploma 3 Akuntansi di Indonesia.

Yuniarta, G. A. (2008). Pengembangan problem based learning dengan Myob accounting pada mata kuliah komputer akuntansi. Jpp Undiksha, 41(1).

Yuniarta, G. A. (2013). Persepsi praktisi akuntansi terhadap kelayakan hasil pengembangan perangkat simulasi akuntansi untuk usaha kecil menengah berbasis multimedia. Jurnal Akuntansi Profesi, 3(1).

Yuniarta, G. A. (2015). Pengembangan software of hospitality accounting dictionary. Jurnal Sains Dan Teknologi, 4(1). 


\section{Lampiran:}

Contoh Form Identifikasi Aplikasi Excel for Accounting (EFA)

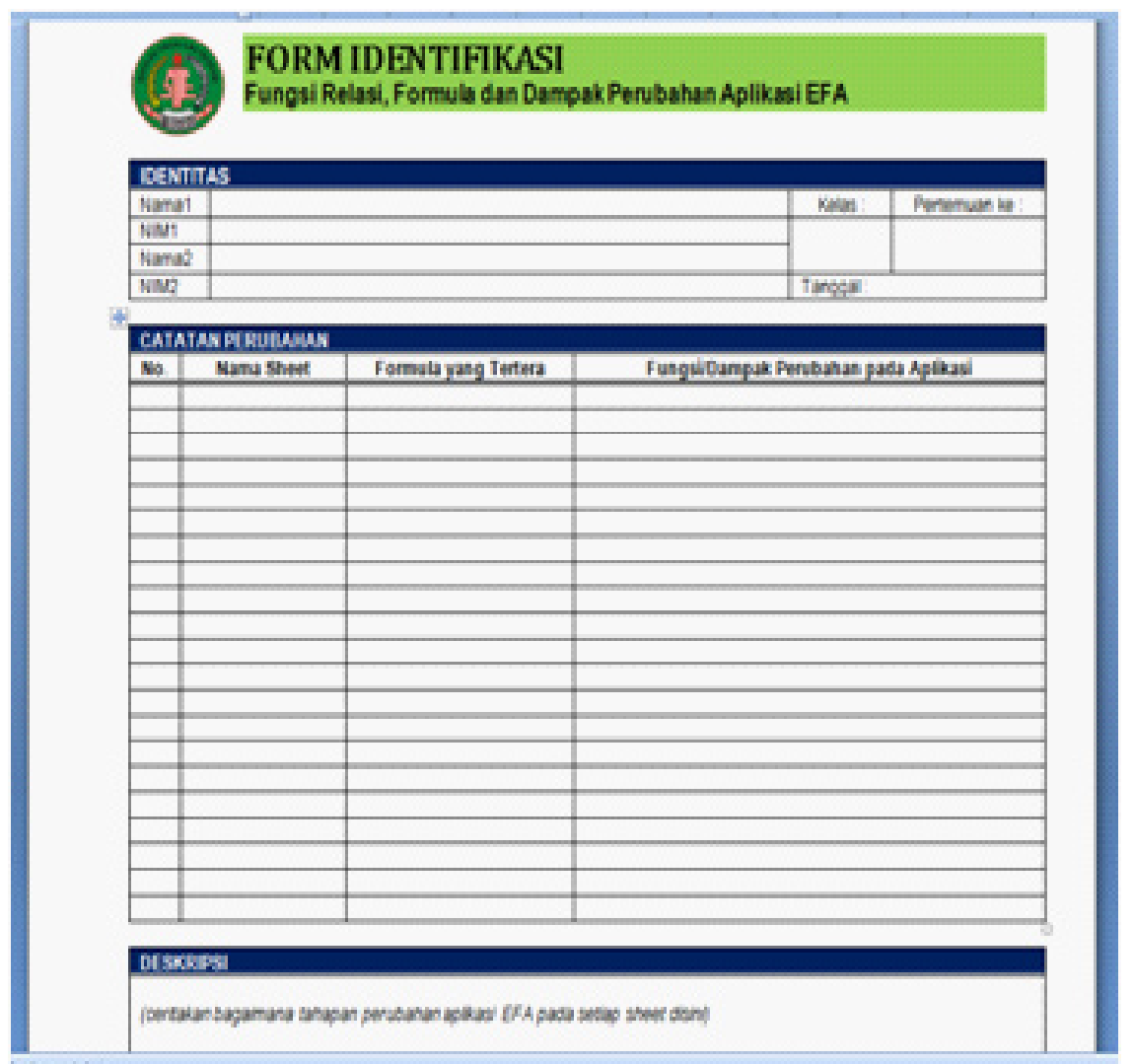

Lampiran Manual User Guide Mahasiswa

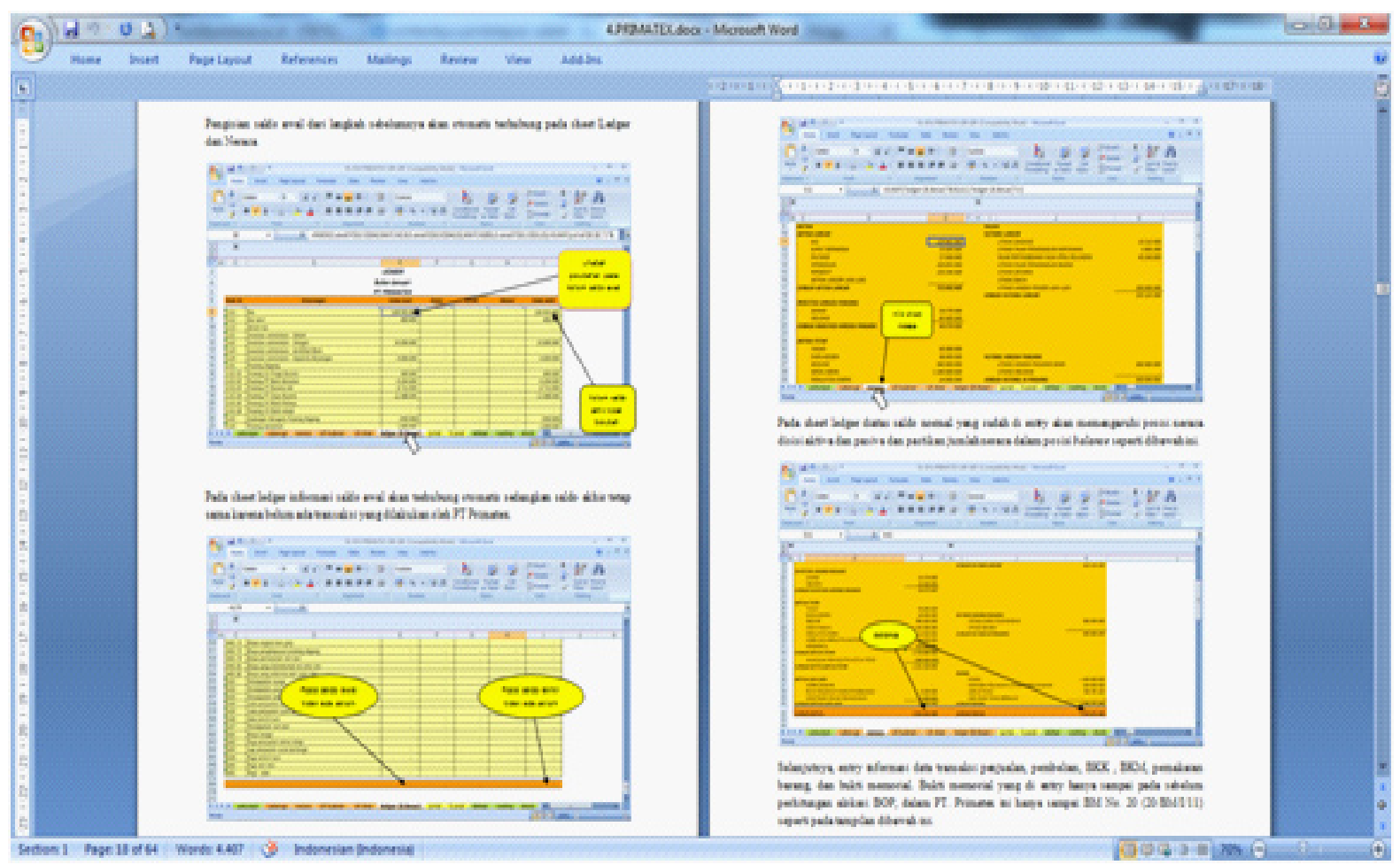




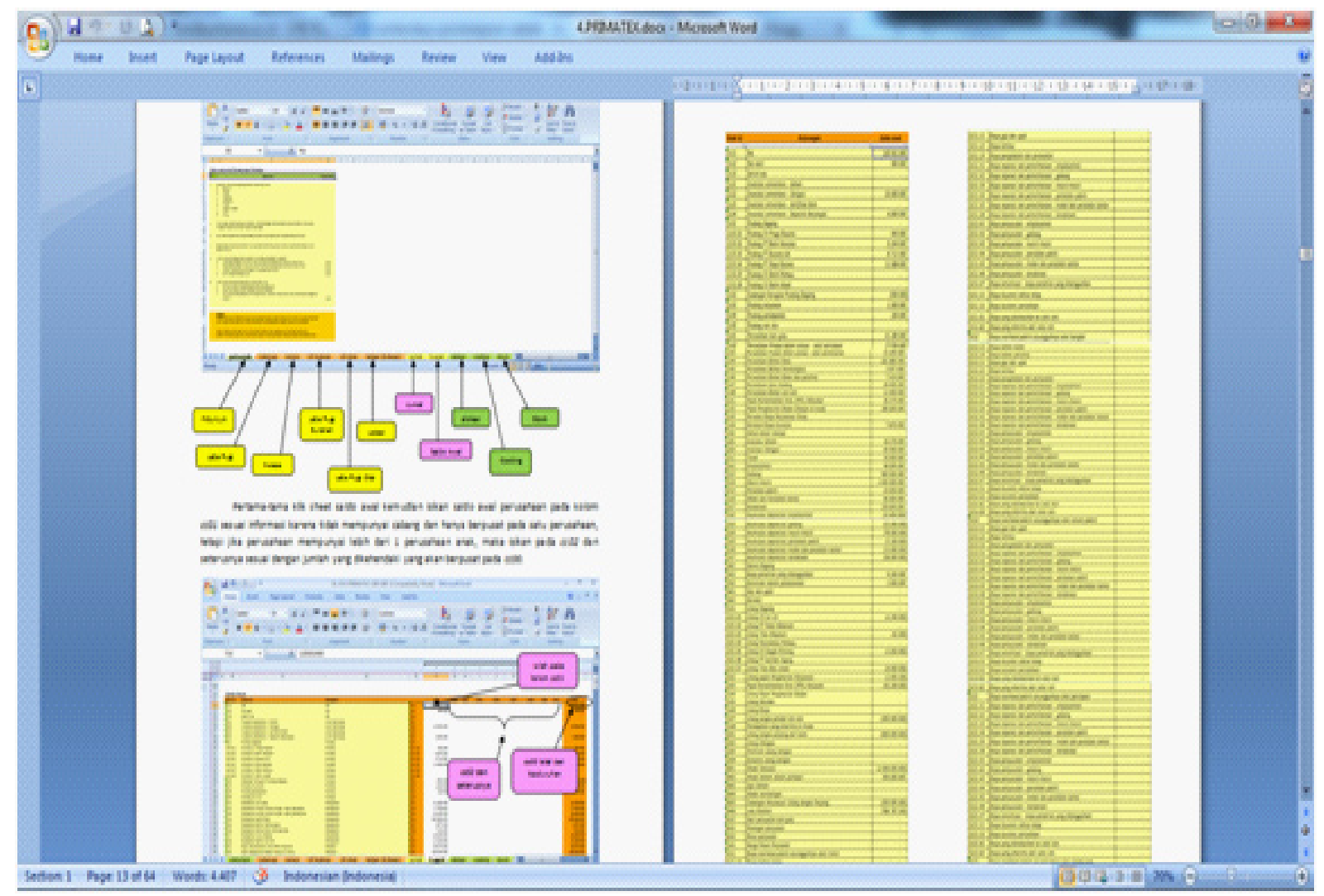

Lampiran Manual User Guide Mahasiswa versi Video Player

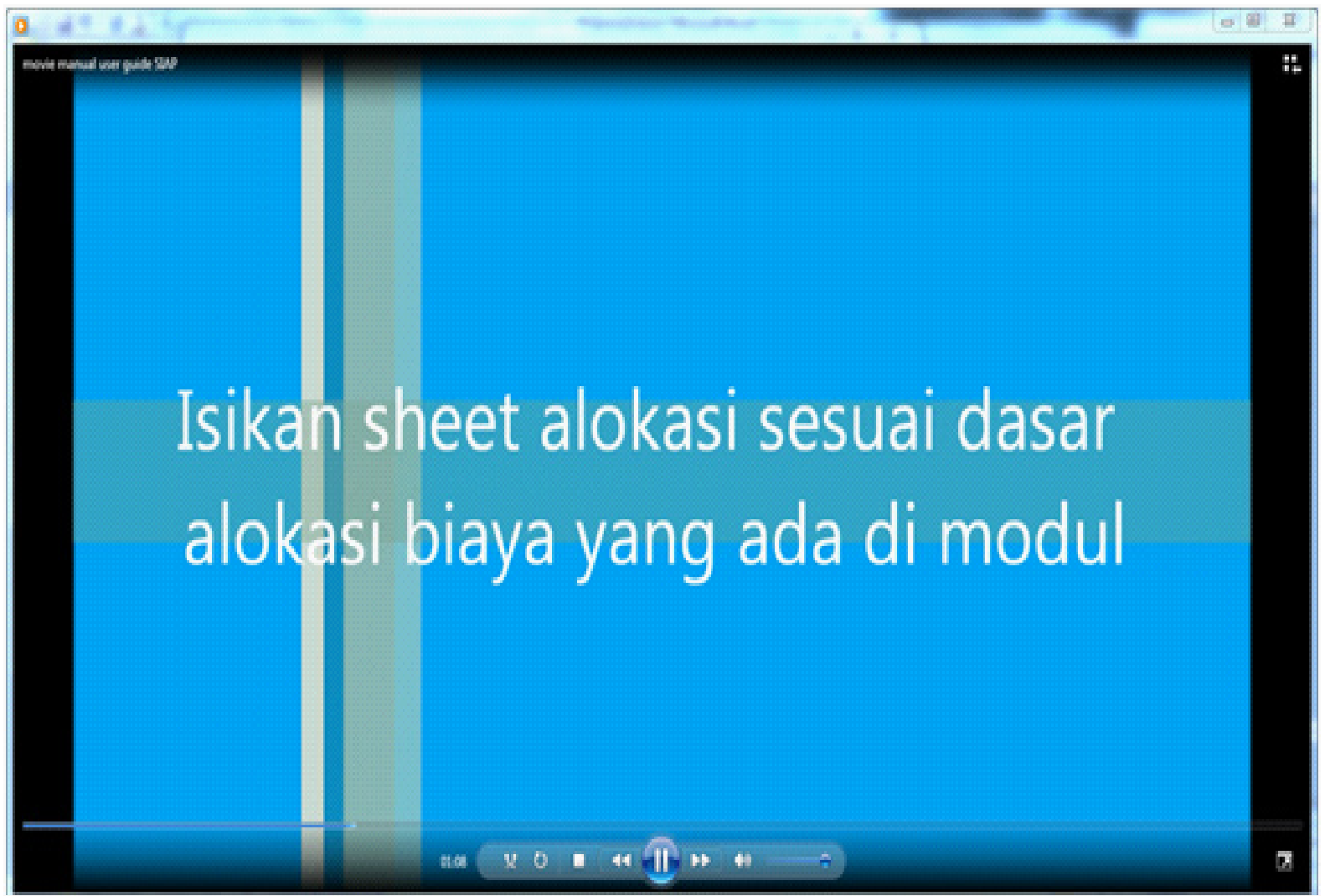

